\title{
Perception of Accounting Students Over Professional Certification Exam: Case Study on Accounting Studies of Vocational UI
}

\author{
Birawani Dwi Anggraeni, Sandra Aulia, and Dewi Kartikasari
}

Accounting Study Program, Vocational Program, Universitas Indonesia

\section{Abstract}

Vocational education is an applied education in which students are required to have professional certification. This research is to delve deeper into student perceptions on professional certification exams in accounting and factors that influence students' decision to follow professional certification. This study used a questionnaire that was distributed to accounting students and collected as many as 157 questionnaires for the purposes of this study. The study used regression analysis and descriptive analysis.

Corresponding Author: Birawani Dwi Anggraeni birawani@yahoo.co.uk

Received: 8 June 2018 Accepted: 17 July 2018 Published: 8 August 2018

Publishing services provided by Knowledge

(c) Birawani Dwi Anggraeni et al. This article is distributed under the terms of the Commons Attribution License, which permits unrestricted use and redistribution provided that the original author and source are credited.

Selection and Peer-review under the responsibility of the 2 nd ICVHE Conference Committee. The results of this research aims to study the program to better play the role of faculty and university management to further influence and motivate students to obtain a professional degree. Students can have a positive impact in the workplace. This study is confined to the accounting program of the students and the sample data used has not been evenly distributed at every level.

Keywords: accounting, professional certification, vocational student

\section{Introduction}

Today Indonesia joined in ASEAN countries has entered a new round Economic Community (AEC) ASEAN where workers from neighboring ASEAN countries can enter the labor market Indonesia so the competition will be intense for workers and prospective workers. MEA is a single market which allows the country to sell goods and services easily to other Southeast Asian countries so that competition among ASEAN countries are increasingly stringent aims for increased foreign investment in the ASEAN region so that jobs and prosperitysociety can be improved. MEA also taps the door has been opened for eight professions that will compete in the MEA undergraduate engineers, architects, accountants, dentists, tourism personnel, personnel surveys, medical and nursing prakisi. Showed the ability to communicate in English, the other ASEAN countries are much better because merekasudah used to communicating in that language. 
Indonesia has a huge potential market share which would invite foreign investors to invest their capital. Increased foreign investment in the ASEAN region for their AEC will cause a need for the number of accountants are increasing. However, if the number of accountants be register seen in Indonesia are still outnumbered by Thailand, Malaysia, Singapore, and the Philippines did not rule out the possibility that the number of accountants in Indonesia will be insufficient for the needs of the market so that accountants from other ASEAN countries will go to Indonesia.

'Currently, Indonesia threatened flooded professional accountants from other ASEAN countries such as the Philippines and Singapore, said Prof David Bond a professor of accounting and finance from the University of Technology Sidney Australia is currently in Jakarta on Thursday, November 19, 2015'. Accounting Indonesia must be ready to equip themselves with certification of professional accountants in order to raise competitiveness in the era of the ASEAN Economic Community (AEC) starting next year, says an Australian academic [3].

Data Indonesian Institute of Accountants (IAI) in February 2014 stated that the availability of professional accountants in Indonesia insufficient working world. Indonesia needs 452,000 professional accountants. Data Centre of Accounting and Appraisal Services (PPAJP), Ministry of Finance noted only available for less than 16 thousand professional accountants. Until early 2014, there are at least 226,000 companies in Indonesia who need the services of an accountant. According to the Ministry of Finance, last year there were about 53,500 accountants be register country. Meanwhile, the Indonesian Institute of Accountants (IAI) expect the number of national firms could break the 100,000 accountant until 2017. Until now, the new IAI members totaled 17,000 accountants.

Competency skills and abilities the English should be improved so as to compete with an accountant country ASEA besides certification for accounting graduates are also needed, according to Prof. David Bond written on Okezone (19 November 2015) Certification professional accountants can provide numerous benefits for accountants and therefore easier to work and highly credibility to welcome and provide opportunities in the ASEAN region.

MEA requires freeing the flow of skilled labor. Therefore, now many people are vying to get a higher academic degree $\left(S_{1} / S_{2} / S_{3}\right)$. But is it true this way is correct? The way it is actually quite true that for an academic environment. But for the working environment is certainly not true. So what is needed in the work environment? The answer is a professional certification. Professional certification is a designation given 
by a professional organization to a person to show that the person is able to perform a specific job or task.

Vocational education programs are expected to direct education graduates are able to work in accordance with the field work. For accounting then the student can work in the industry as a junior staff as a junior staff accountant or auditor. Therefore, students are expected to have a certification that can support their competence. Certification that already exist today as certificated technicians accounting organized by the Professional Certification Institute Tehnisi Accountants (LSP-TA) under the auspices of BNSP, certified accountant international level, namely 'Diploma in Accounting and Business' organized by the Association of Chartered Certified Accountant (ACCA), Professional Certified Associate certification exam Auditor held by the Indonesian Institute of Accountants (Certified).

This research question to try to answer the factors that influence students' perceptions on the certification exam in accounting student vocational program. The case studies in the research seeks to clarify some questions: 1. Is the accounting student vocational program or party aware of any association which organizes the certification exam? 2. Does the accounting students have the interest to take the certification exams? 3. What factors encourage students accounting certification program? 4. Does gender influence someone to take the certification exams?

\section{Review Literature}

Underlying theoretical framework is based on several studies limited research that has been done abroad. Brown et al. (2002) claim Parsons (1909) as the embryo that encourages conceptual framework helps explain the choice of one's career. Some literature also refers to the psychological factors that influence a student's career choice

Paolillo and Estes (1982), his work describes some factors that affect the professional career on four areas, namely accounting, law, engineering, and health experts conducted in the United States.

Several studies conducted to find the relationship between accounting student career decisions and matters affecting vocational factors. Research Felton et al. (1994) produced a correlation between student majoring in business decisions in Canada to choose a career as a 'Chartered Accountants (CA)'.

Several studies have previously been conducted by Sugahara et al. (2008), Kloot et al. (2007), Said et al. (2004) and Omar (2009) gives the results of research where 
there are a variety of reasons that can affect the careers of graduates in the decision as accountant professional. Sughara et al. (2008) discuss the factors related to the student experience; while Said et al. (2004) related factors that the salary offer to students so as to give the perception of job options. While Kloot et al. (2007), Ahmadi et al. (1995) and Omar (2009) gives the kakrir studies graduates are influenced by gender. Suhara et al. (2008), Omar (2009) and Kloot et al. (2007) also states influenced by a qualified professional career. According to Mc Lean et al. (1996) salary is one of the factors that motivate a person in career selection. Horowitz and Riley (1990) also explained that one of the main criteria that influence the decision of a student's career is the salary offer from the company.

Omar (2009) explains in his research that one of the factors that are common in accounting students will reconsider their perceptions of the profession. Some of the students thought it would be difficult to pass a professional program in accounting that few of them were able to pass the exam. Omar study (2009) showed that students in Malaysia still have a bad perception Yag on professional accounting program, especially on steeper institute students were also investigated by [1]. According to Abdullah (2001) students feel difficulties in the exam and they are trying beberapakali to pass the exam.

In research Sugahara and Bolland (2006) that replicate the study of Omar (2009) conducted in Japan, the results of their study showed that students who are non-CPAs tend to see the CPA as a profession have the communication skills are low, have career prospects are few and usually dominated by men. This study simply compare statistics on the perception of the CPA exam among students who are interested in becoming a CPA and are not interested, but the implications for understanding the influence of the factors that determine the career of a CPA.

Several previous studies mention the existence of gender differences in the perceptions of accountants where men show interest in the accounting profession and they need a higher education than women [9]. Nelson and Vendrzyk research (1996) conducted in the USA informs that women have greater interest rate than the male students. While the research Jackling and Calero (2006) said their study found no significant difference between women and men to become accountants. 


\section{Methodology}

Cooper and Emroy (1995) stated that "the purpose of the descriptive study was to study, who, what, when, where, and how ketikad related to the topic." This study may be simple or complex and can coinciding with keperuntukkannya.

Sekaran (2000) identified several benefits of descriptive research: 1. Assist in decision-making 2. Provide information and data for further research 3. Develop an understanding of a group.

According Sugiyono (2012: 13) descriptive research that studies conducted to determine the value of an independent variable, either a variable or more without making comparisons, or connect with other variables. Descriptive research used is unwilling case study to analyze the conditions prevailing at this time with the campus environment.

\section{Data Collection}

The data collected in this study are primary data in the form of data obtained from questionnaires. The spread of this questionnaire addressed to students of vocational program in Accounting. The questionnaire used in this research is a closed question. Questions on the questionnaire is divided into two, namely the first to know sebearapa much respondents know the certification exam related to accounting and the second part to determine whether the respondents are willing to take a certification examination and their perceptions of the test. The research process refers to a review of the literature on a particular area of research.

Data collection techniques used in this study is a random sampling in which every accounting student vocational program has the same chance of being selected as a sample. The location of this research is done in Depok, in the period from May to September, 2016.

\section{Respondents}

Data were analyzed using tables. Questions on the questionnaire consists of yes/no questions and rank the perception. The population is all students to 510 students of vocational accounting consists of three forces are forces in 2013, 2014 and 2015. While the sample using random method (random sampling) where every student has the same opportunity to become respondents. 
TABLE 1: Summary questionnaire respondents.

\begin{tabular}{l|c|}
\hline Information & Total \\
\hline Population & 510 \\
\hline Questionnaire & 200 \\
\hline Complete Questionnaire & 157 \\
\hline
\end{tabular}

\section{Data Processing}

In this study, 157 subjects the data was collected which consisted of 53 respondents are male and 104 respondents were women.

TABLE 2

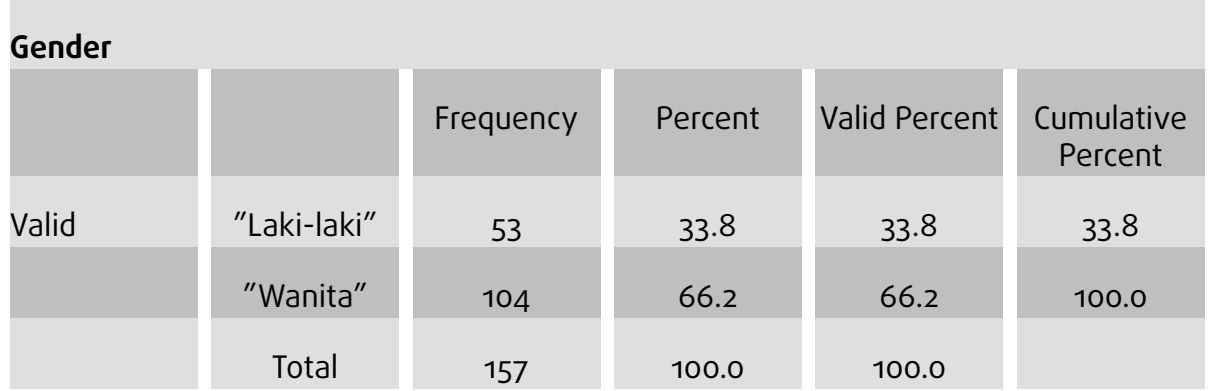

The majority of the 157 respondents age 15-18 years age range of respondents as many as 18 respondents $11.5 \%, 134$ respondents (84.8\%) were aged $19-21$ years and 4 respondents aged $>21$ years.

TABLE 3

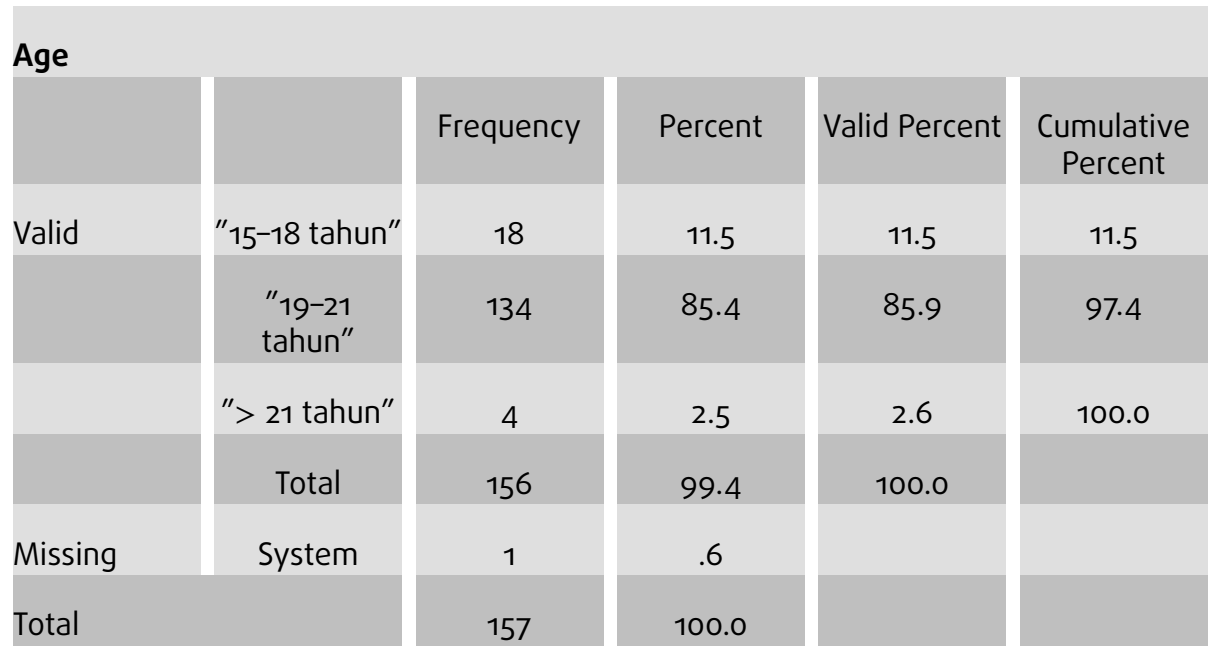

Of the 157 respondent data as much as 33 respondents (21.2\%) first-rate, 75 respondents $(48.1 \%)$ level two and 48 respondents (30.6\%) and three levels of three respondents did not fill in the data. 
TABLE 4

\begin{tabular}{|c|c|c|c|c|c|}
\hline \multicolumn{6}{|l|}{ Level } \\
\hline & & Frequency & Percent & Valid Percent & $\begin{array}{c}\text { Cumulative } \\
\text { Percent }\end{array}$ \\
\hline \multirow[t]{4}{*}{ Valid } & semester 2 & 33 & 21.0 & 21.2 & 21.2 \\
\hline & semester 4 & 75 & 47.8 & 48.1 & 69.2 \\
\hline & semester 6 & 48 & 30.6 & 30.8 & 100.0 \\
\hline & Total & 156 & 99.4 & 100.0 & \\
\hline Missing & System & 1 & .6 & & \\
\hline Total & & 157 & 100.0 & & \\
\hline
\end{tabular}

\section{Research Result}

The number of samples distributed 200 questionnaires, where as many as 170 questionnaires were returned questionnaires and 157 questionnaires can be used as data to be diolah. Hasil gained as much as 20 respondents did not know issuer associations and 137 respondents, knowing the association.

TABLE 5
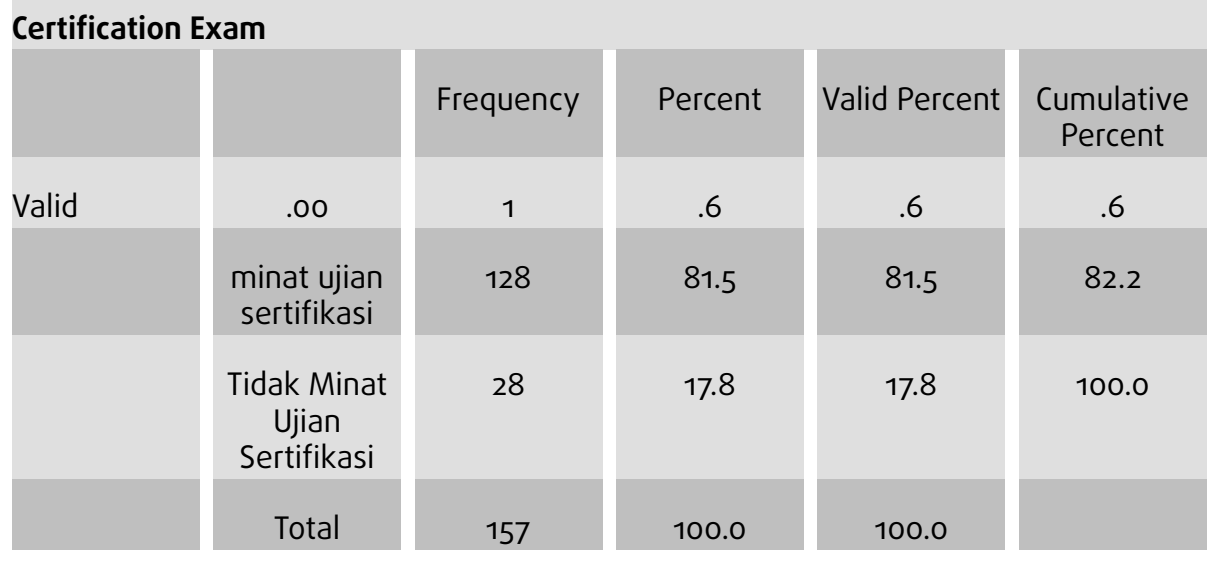

A total of 128 respondents said they would take the certification exams while 28 respondents said it would not follow the certification and the first respondent did not give an opinion

Male respondents as many as 53 respondents, 46 respondents expressed interest in the certification exam, while the rest are not interested. Female respondents as many as 104 people, 82 diantarannya interest sertikasi exam.

For the 28 respondents who denied certification exams because of their perceptions of the certification exam is as follows: 


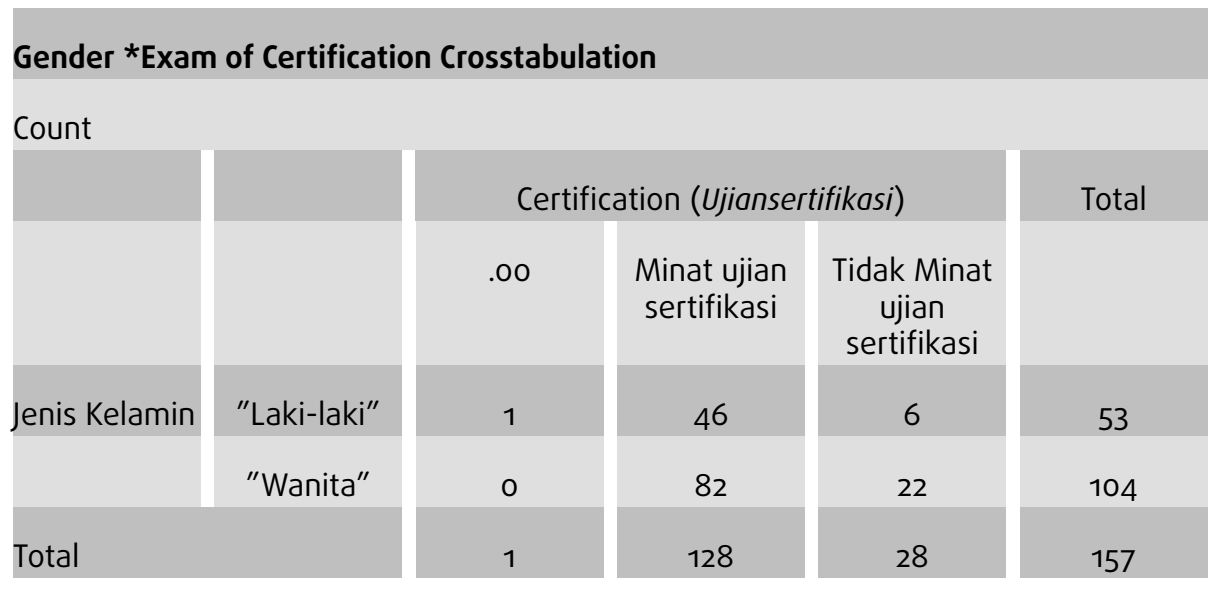

TABLE 7: Rating respondents of reason rejections of certification exam.

$\begin{array}{ll}\text { No. The reason based on Rank } \\ 1 & \text { Certification Expensive and Difficult } \\ 2 & \text { Certification does not reflect my ability } \\ 3 & \text { Certification does not provide prestige for me } \\ 4 & \text { The Company does not require certified staff } \\ 5 & \text { Certification does not benefit me in getting a job } \\ 6 & \begin{array}{l}\text { Other reasons: I am not interested and do not want to } \\ \text { be an accountant Accounting is not a suitable } \\ \text { profession for me I do not know what the certification } \\ \text { would come, but I know that it is important }\end{array}\end{array}$

Based on Table 2, it can be an outline of the majority of respondents who refused to take the certification exams because their perception is 'certification was expensive and difficult'. Respondents who reject the certification exams in general are students who feel they do not fit in the accounting field. A total of 13 female respondents and 10 male respondents who refuse certification exam. Dari 128 respondent, kami kemudian menelaah ulang, persepsi apa yang ada pada benak mereka sehingga mereka berminat untuk mengikuti ujian sertifikasi. Hasil yang kami peroleh adalah sebagai berikut:

Of the 128 respondents, 67 respondents with their certification will provide greater opportunities than the accountant who does not have the certification, 23 respondents (18\%) certification will give confidence to the respondents, 34 respondents said they would provide a guarantee for a better career in the future and higher salaries, and 4 respondents give a sense of prestige for the individual.

For the second, 47 respondents $(36.7 \%)$ have the perception that the certification will provide higher salaries than workers who do not have certification. 
TABLE 8

\begin{tabular}{|c|c|c|c|c|c|}
\hline \multicolumn{6}{|c|}{ First rank } \\
\hline & & Frequency & Percent & Valid Percent & $\begin{array}{l}\text { Cumulative } \\
\text { Percent }\end{array}$ \\
\hline \multirow[t]{6}{*}{ Valid } & $\begin{array}{l}\text { Memberikan Peluang Lebih } \\
\text { Besar }\end{array}$ & 67 & 52.3 & 52.3 & 52.3 \\
\hline & $\begin{array}{l}\text { Memberikan Gaji yang } \\
\text { lebih tinggi }\end{array}$ & 17 & $13 \cdot 3$ & $13 \cdot 3$ & 65.6 \\
\hline & $\begin{array}{l}\text { Memberikan Jaminan } \\
\text { jenjang karir yang lebih } \\
\text { baik }\end{array}$ & 17 & 13.3 & 13.3 & 78.9 \\
\hline & $\begin{array}{l}\text { Memberikan rasa percaya } \\
\text { diri atas kemampuan } \\
\text { pribadi }\end{array}$ & 23 & 18.0 & 18.0 & 96.9 \\
\hline & $\begin{array}{l}\text { Memberikan rasa prestise } \\
\text { bagi saya }\end{array}$ & 4 & 3.1 & 3.1 & 100.0 \\
\hline & Total & 128 & 100.0 & 100.0 & \\
\hline
\end{tabular}

TABLE 9

\section{Second rank}

\begin{tabular}{|c|c|c|c|c|c|}
\hline & & Frequency & Percent & Valid Percent & $\begin{array}{l}\text { Cumulative } \\
\text { Percent }\end{array}$ \\
\hline \multirow[t]{7}{*}{ Valid } & .00 & 1 & .8 & .8 & .8 \\
\hline & $\begin{array}{l}\text { Memberikan Peluang Lebih } \\
\text { Besar }\end{array}$ & 16 & 12.5 & 12.5 & $13 \cdot 3$ \\
\hline & $\begin{array}{l}\text { Memberikan Gaji yang } \\
\text { lebih tinggi }\end{array}$ & 47 & 36.7 & 36.7 & 50.0 \\
\hline & $\begin{array}{l}\text { Memberikan Jaminan } \\
\text { jenjang karir yang lebih } \\
\text { baik }\end{array}$ & 24 & 18.8 & 18.8 & 68.8 \\
\hline & $\begin{array}{l}\text { Memberikan rasa percaya } \\
\text { diri atas kemampuan } \\
\text { pribadi }\end{array}$ & 26 & 20.3 & 20.3 & 89.1 \\
\hline & $\begin{array}{l}\text { Memberikan rasa prestise } \\
\text { bagi saya }\end{array}$ & 14 & 10.9 & 10.9 & 100.0 \\
\hline & Total & 128 & 100.0 & 100.0 & \\
\hline
\end{tabular}

A total of 48 respondents have a perception with their certification will provide a guarantee on a career path for those who have certification

In fourth place, as many as 40 respondents (31.3\%) had a perception with their certification will give confidence in his ability. 
TABLE 10

\begin{tabular}{|c|c|c|c|c|c|}
\hline \multicolumn{6}{|c|}{ Third rank } \\
\hline & & Frequency & Percent & Valid Percent & $\begin{array}{l}\text { Cumulative } \\
\text { Percent }\end{array}$ \\
\hline \multirow[t]{7}{*}{ Valid } & .00 & 2 & 1.6 & 1.6 & 1.6 \\
\hline & $\begin{array}{l}\text { Memberikan Peluang Lebih } \\
\text { Besar }\end{array}$ & 14 & 10.9 & 10.9 & 12.5 \\
\hline & $\begin{array}{l}\text { Memberikan Gaji yang } \\
\text { lebih tinggi }\end{array}$ & 23 & 18.0 & 18.0 & 30.5 \\
\hline & $\begin{array}{l}\text { Memberikan Jaminan } \\
\text { jenjang karir yang lebih } \\
\text { baik }\end{array}$ & 48 & 37.5 & 37.5 & 68.0 \\
\hline & $\begin{array}{l}\text { Memberikan rasa percaya } \\
\text { diri atas kemampuan } \\
\text { pribadi }\end{array}$ & 21 & 16.4 & 16.4 & 84.4 \\
\hline & $\begin{array}{l}\text { Memberikan rasa prestise } \\
\text { bagi saya }\end{array}$ & 20 & 15.6 & 15.6 & 100.0 \\
\hline & Total & 128 & 100.0 & 100.0 & \\
\hline
\end{tabular}

TABLE 11

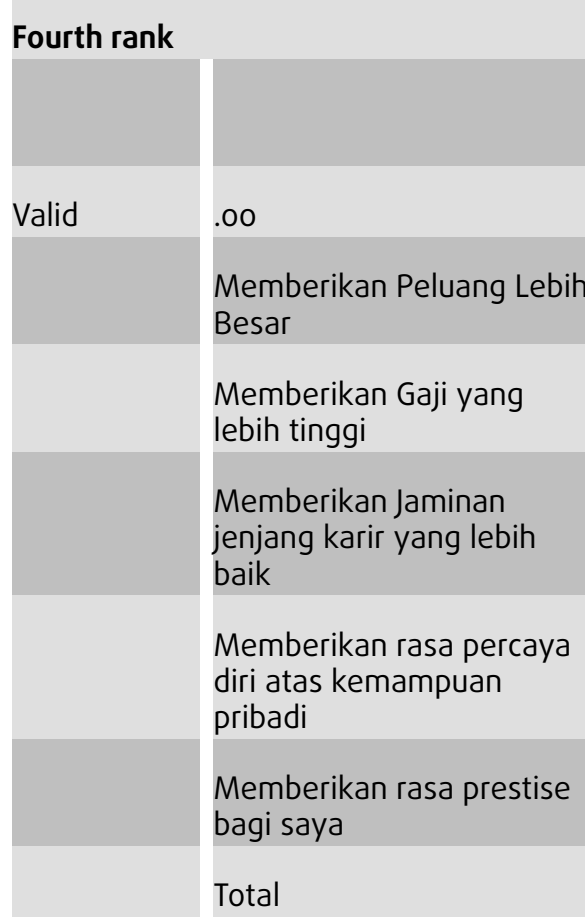

\begin{tabular}{|c|c|c|c|}
\hline Frequency & Percent & Valid Percent & $\begin{array}{c}\text { Cumulative } \\
\text { Percent }\end{array}$ \\
\hline 4 & 3.1 & 3.1 & 3.1 \\
\hline 13 & 10.2 & 10.2 & 13.3 \\
\hline 25 & 19.5 & 19.5 & 32.8 \\
\hline 23 & 18.0 & 18.0 & 50.8 \\
\hline 40 & 31.3 & 31.3 & 82.0 \\
\hline 23 & 18.0 & 18.0 & 100.0 \\
\hline 128 & 100.0 & 100.0 & \\
\hline
\end{tabular}

In the fifth, as many as 67 respondents (52.3\%) have a perception provides a sense of prestige for the individual.

From the aforementioned results, if made a summary, as follows: 
TABLE 12

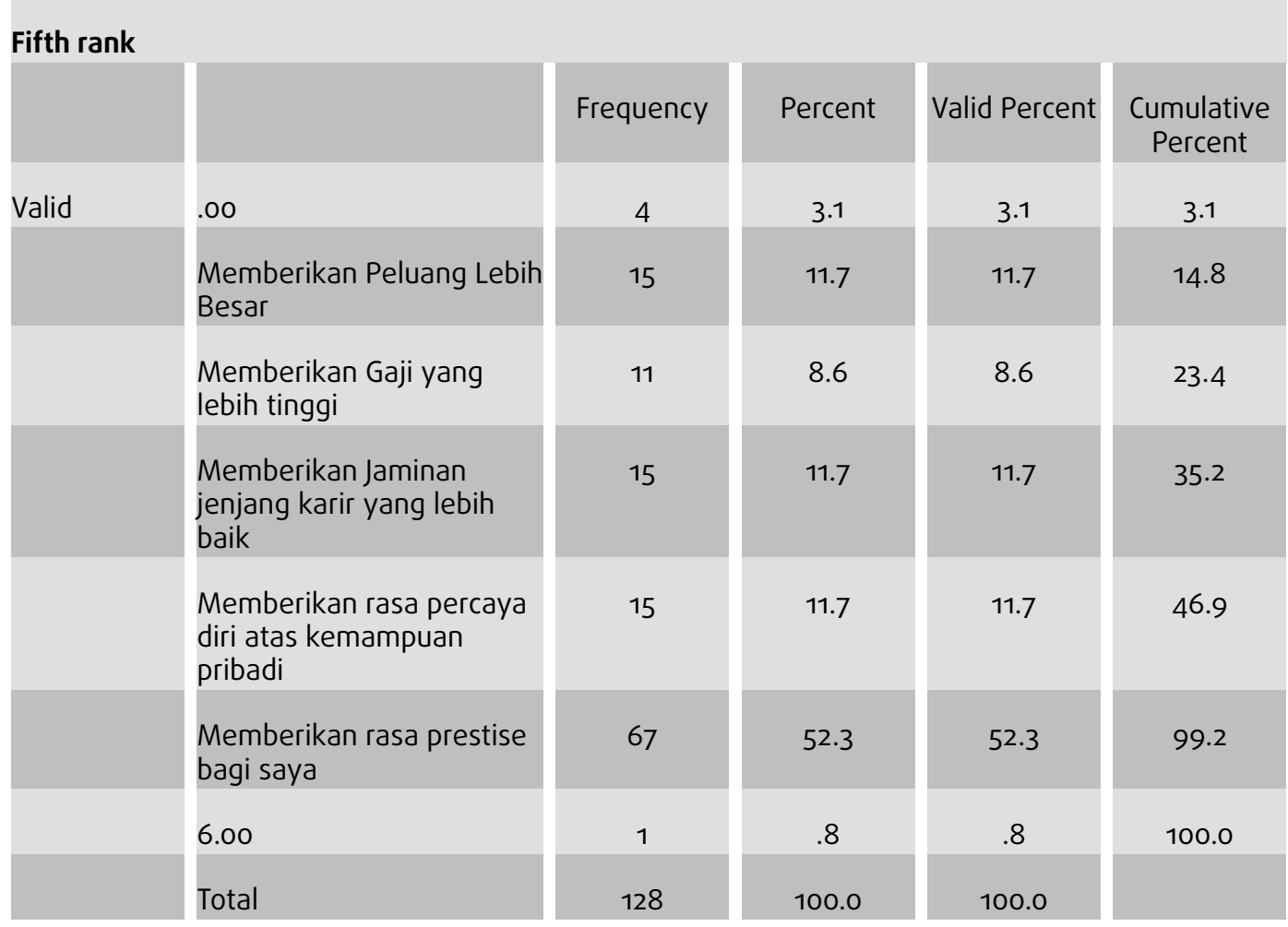

TABLE 13: Summary Research Result.

\begin{tabular}{|l|l|c|c|}
\hline No. & Perceptions & Rank & Percentage \\
\hline 1. & $\begin{array}{l}\text { Certification will provide greater opportunities than } \\
\text { those who do not have certification }\end{array}$ & First & $52.3 \%$ \\
\hline 2 & $\begin{array}{l}\text { Certification will provide an opportunity to get a job } \\
\text { with a higher salary }\end{array}$ & Second & $36.7 \%$ \\
\hline 3 & $\begin{array}{l}\text { Certification provides assurance of a better career } \\
4\end{array}$ & Certification provides confidence in my ability & Third \\
\hline 5 & Certification provides a sense of prestige for me & Fifth & $37.5 \%$ \\
\hline
\end{tabular}

\section{Conclusion}

The results of this study resulted in a general overview of the vocational program accounting student perceptions regarding the certification exam. In this research shows the majority of accounting students know their certification programs organized by the association. The respondents know the main association that organizes certification of the Indonesian Institute of Accountants (IAI), the Indonesian Institute of Accountants (Certified), Association of Chartered Certified Accountant (ACCA), and associations or other parties as well as parties organized Accurate Brevet exam. But the majority of 
respondents have not been able to state with both a degree that would be obtained after the certification exam.

The results of this study also showed that the majority of interest for the certification exam. Only a small proportion who refuse the certification exam because respondents do not have an interest in accounting

The majority of respondents in this study were women, thus affecting the results of studies in which women have a tendency to take a certification examination. This contrasts with research conducted by Heiat et al. (2007) and Jackling and Calero (2006) but in line with research conducted by nelson and Vendrzyk (1996) The perception that the certification will provide a greater opportunity in obtaining jobs into perception The main respondents. The results are consistent with research Suhara et al. (2008), Omar (2009) and Kloot et al. (2007) where careers are influenced by the professional qualification through professional certification in accounting. This is slightly different to the research conducted by Said et al. (2004) in which the salary of a top priority on the students when they choose a job. But in this study also shows that the certification will affect the amount of salary they earned while working.

Given these perceptions, respondents believed that they would be able to compete with accountants who come from neighboring countries in the framework of MEAs. These results also provide a general idea that the shortage of accountants in the future can be resolved by further increasing socialization to accounting students so that they understand the flow of the certification process.

\section{Benefit of Research}

1. There have been many studies related to the perception of accounting students both domestically and abroad, but there is no research to students of vocational accounting

2. The results of this basic research can provide input for Accounting Studies Program to make improvements in terms of curriculum and improve student perceptions

3. The results of this study encourage Accounting Studies Program to further enhance the awareness of students about the test track sertikasi and the benefits to be gained student 


\section{Limitation This Study}

1. Research conducted limited only students of Vocational Sector Accounting Studies Program, so the limited number of samples and cannot be generalized to be generally applicable to other vocational education

2. Limitations of time to research conducted by the researchers to complete this study less than a year, so cannot describe the overall difference between the perception of force

\section{References}

[1] Abdullah, M. (2001). Professional accountant: Malay students' bad perceptions. Diambil kembali dari http://www.utusan.com.my/utusan.

[2] Ahmadi, M., Helms, M. M., \& Nodoushani, P. (1995). A Factors Analytic Approach Profiling Job Selection differences of male and female accountants. Manajerial Auditing Journal, 17-24.

[3] ant. (2015, November Kamis). (Okezone, Produser) Dipetik September Jumat, 2016, dari http://economy.okezone.com/read/2015/11/19/320/1252060/indonesiaharus-sertifikasi-akuntan-hadapi-mea

[4] Boland, G., \& Sugahara, S. (2009). The Accounting Profession as a Career Choice for Tertiary Business. Accounting Education.

[5] Cory, S. N., Martinez, G., \& Reeves, T. E. (t.thn.). African American High School Student Perceptions of Accountans. SBAJ, 10(1), 17-37.

[6] D, B., \& Associates. (2002). Career Choice and Development (4 ed.). San Fransisco: Jossey Bass.

[7] Feltons, S. B., \& al, e. (1994). Factors Influencing the business student's choices of a career in chartered accountancy. Accounting Education, 131-141.

[8] Hashim, H. M., Embong, A. M., \& Shaari, Z. H. (2012). Perceptions on Accounting Career: A Study among the secondary School Students in a Regional Kelantan State. World Academy of Science, Engineering and Technology International Journal of Social, Behavioral, Educational, Economic, Business and Industrial Engineering, $6(12)$.

[9] Heiat, A., Brown, D., \& D, M. J. (2007). An Empirical Analysis of Underlying Factors Affectiing The Choice of Accounting Major. Journal of College Teaching and Learning, $4(8), 83-98$. 
[10] Horowitz, K., \& Riley, T. (1990). How do accouting students see us. Accountancy, 75-79.

[11] Jackling, B. (2002). Are negative perceptions of the accounting profession perpetuated by tertiary accounting course in? An Australian Perspective. Asia review of Accounting, 10, 52-80.

[12] Jackling, B., \& Calero, C. (2006). Influence on undergraduate students' intentions to become qualified accountants: Evidence from Australia. Accounting Education: An international journal, 419-438.

[13] Kloot, L., Marles, K., \& Vinen, D. (1999). Professional Accounting Qualification Choices: Do gender, etnicity, university and selection process matter. Asian Review Accounting, 131-143.

[14] Mc Lean, E. R., Smits, S. J., \& Tanner, J. R. (1996). The Importance of Salary on Job and Career Attitudes of Information Systems Professional. Journal Information nd Management, 291-299.

[15] Molloy, M. (2009). What Influences Accounting Student's Attitudes towards the Accounting Profession- A North West Experience. Letterkenny Institute of Tecnoogy.

[16] Mustapha, M., \& Abu Hassan, M. H. (2012). Accounting Student's Perception on Pursuing Professional Examination. International Journal of Accounting, 4(4).

[17] Nelson, I., Vendrzyk, V. P., Quirin, J. J., \& Allen, R. D. (2002). No, the sky is not falling the evidence of accounting student characteristics at FSA School. Accounting Edition, 277-279.

[18] Omar, N. (2009). Factors Influencing the Diploma in Accounting (DIA) Students Decision To Pursue Professional Accounting Programmes. College of Business. Kedah Darul Aman: Universiti Utara Malaysia.

[19] Paolillo, G. J., \& Estes, W. R. (1982). AN Empirical Analysis of career choice factors among accountants, attorney, engineers, and physicians. The Accounting Review, 785-793.

[20] Perkasa, Y. B. (2011). PENGARUH MOTIVASI TERHADAP MINAT MAHASISWA UNTUK MENGIKUTI PENDIDIKAN PROFESI AKUNTANSI.

[21] Said, J., Ghani, E. K., Hasim, A., \& Nasir, N. M. (2004). Perception towards accounting career among Malaysian undergraduates. National Accounting Research Journal, 31-42.

[22] Sekaran, U. (2009). Metodologi Penelitian untuk Bisnis. Jakarta: Salemba Empat.

[23] Steadman, G., \& Huang, A. (1996). Factors Influencing choice of accounting disipline culture and gender differences. Accounting Reasearch Journal, 9, 82-89. 
[24] Sugahara, S., \& Boland, G. (2006). Perceptions of the Certified Public Accountants by accouting and non-accounting tertiary students in Japan. Asian Review of Accounting, 149-167.

[25] Sugahara, S., \& Boland, G. (2009). The Accounting Profession as a Career Choice for Tertiary Business Students in Japan-A Factor Analysis. Accounting Education, 255272.

[26] Sugahara, S., Hiramatsu, K., \& Boland, G. (2008). The Factors influencing accounting students's career intention to become a Certified Public Accountant in Japan. Asian Review Accouting, 5-22.

[27] Sugiyono. (2012). Memahami Penelitian Kualitatif. Bandung: Alfabeta. 